\title{
A mysterious visitor to the heart
}

\author{
Ranjan Shetty, ${ }^{1}$ G Vivek, ${ }^{1}$ Satish Nayak, ${ }^{2}$ Lorraine Dias $^{2}$ \\ ${ }^{1}$ Department of Cardiology, Kasturba Medical College, Manipal, Karnataka, India \\ ${ }^{2}$ Department of Internal Medicine, Kasturba Medical College, Manipal, Karnataka, India
}

Correspondence to Dr G Vivek, vivekgraman@gmail.com; vivekgraman@yahoo.co.in

\section{DESCRIPTION}

A 55-year-old man with a history of hypertension was admitted with complaints of progressive breathlessness of 2 months duration. General physical examination was remarkable for an elevated jugular venous pressure and bilateral pedal oedema. His ECG showed normal axis, left ventricular hypertrophy by voltage criteria and associated left atrial enlargement. Echocardiogram (ECHO) revealed multiple, mobile, hyperechoic masses with central lucency in the left ventricle (LV) attached to the apex, septum and free wall. The cyst wall had double echogenic lines separated by a hypoechogenic layer suggestive of hydatid cyst disease (figure 1). ${ }^{1}$ In addition, his LV was globally hypokinetic with an ejection fraction (EF) of $25 \%$. CT of the chest with contrast showed non-calcified, hypointense masses surrounded by a high-attenuation wall, in the LV cavity which was consistent with hydatid cyst (figure 2). ${ }^{1}$ No hepatic cysts could be demonstrated. ELISA for the detection of anti-Echinococcus antibodies (IgG) in serum was negative. Coronary angiogram showed no significant obstructive lesions. Surgical removal of the cysts was planned. Preoperatively he was started on oral albenadazole $400 \mathrm{mg}$ twice a day. Repeat ECHO after 5 days showed significant resolution of the cysts; surgery was deferred. The cysts completely resolved with 1 month of albenadazole therapy alone. His LVEF had improved to $40 \%$ at follow-up.

Echinococcosis or hydatid cyst disease is a tissue infestation. Cardiac involvement is extremely rare $(0.5-2 \%){ }^{2}$ Complications of the same can present as intracardiac mass lesions, with valvular impingement and, as congestive cardiac failure. Most dramatic presentation would be as systemic embolism or cyst rupture with anaphylactic shock. ${ }^{3}$ ECHO, CT and MRI are important diagnostic tools. ${ }^{1}$ Serology (ELISA) for hydatid antigen is positive in only $40-50 \%$ of cardiac hydatid disease and $80 \%$ in hepatic involvement. Treatment options include either drug therapy and/or surgery, which have to be weighed against the rare occurrence of embolisation of the cysts from the LV or the sudden rupture with a catastrophic anaphylaxis from the cyst debris.

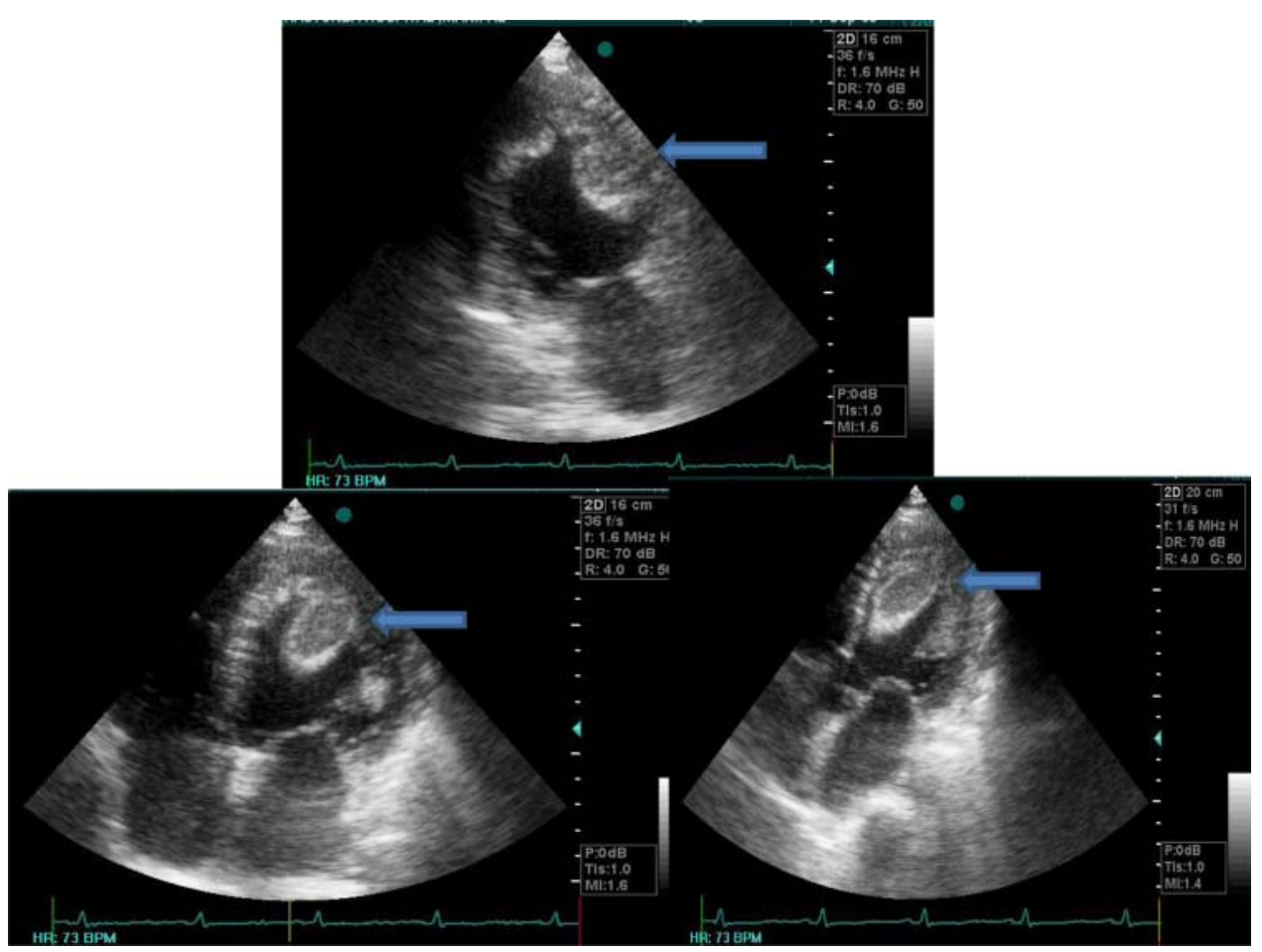

Figure 1 Echocardiogram showing multiple hyperechoic masses with central lucency (arrows) in the left ventricle. 


\section{BMJ Case Reports}

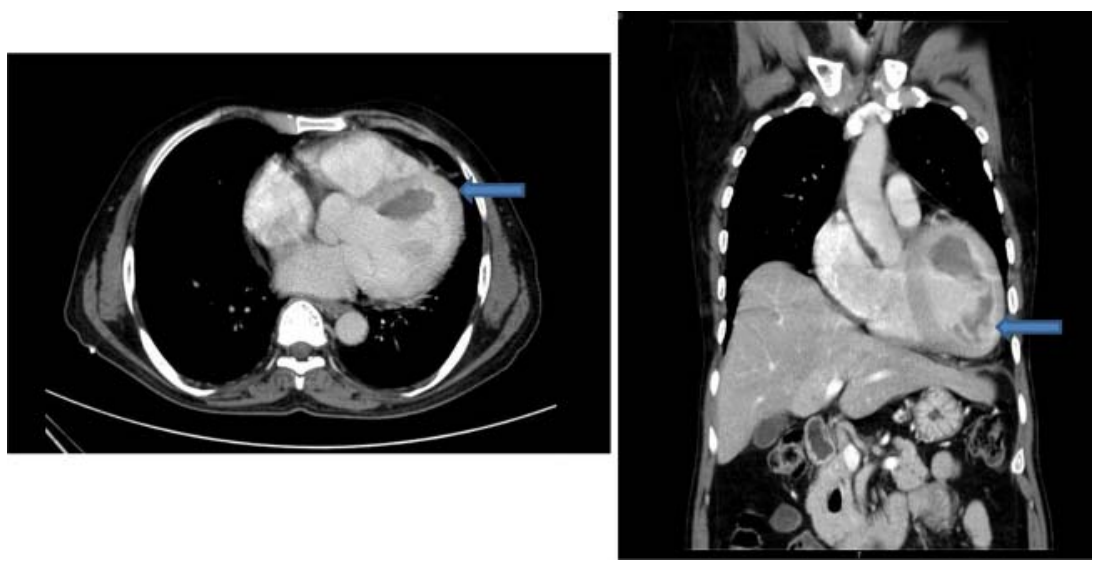

Figure 2 CT of the chest with contrast in transverse and coronal section showing hypoechoic cysts in the left ventricle (arrows).

Definitive treatment involves surgical removal of the cysts along with albenadazole for a period of 4-6 weeks. ${ }^{4}$ An alternate regimen would be a 4 -week course repeated after 2 weeks of no treatment, to a total of three treatment cycles. Surgery is complicated by extremely friable cysts with the accompanying risk of anaphylaxis. Complete resolution of hydatid cysts with medical therapy alone is very rare, as in our patient who was asymptomatic at 1-year follow-up with no recurrence of the cysts. However, the patient is being monitored with a 3-monthly ECHO, as studies have shown a recurrence of cysts up to 2 years after therapy. ${ }^{5}$

\section{Learning points}

- Cardiac hydatid disease is an extremely rare disease and should be a differential diagnosis for mass lesions in developing countries.

- Definitive therapy involves surgical removal of the cysts and a course of albenadazole for a minimum period of 4-6 weeks.

- Resolution of cysts with medical therapy alone as in our patient is rare. However, multiple relapses of cysts are known to occur up to 2 years after initiation of therapy.

\section{Competing interests None.}

Patient consent Obtained.

\section{REFERENCES}

1. Dursun M, Terzibasioglu E, Yilmaz R, et al. Cardiac hydatid disease: CT and MRI findings. AJR Am J Roentgenol 2008;190:226-32.

2. Dighiero J, Canabal ES, Aguirre CV, et al. Echinococcus disease of the heart. Circulation 1958:17:127-32.

3. Di Bello R, Menenotez H. Intracardiac rupture of hydatid cysts of heart. A study based on three personal observations and 101 cases in world literature. Circulation 1963:27:366-74.

4. Kaplan M, Demirtas M, Cimen S, et al. Cardiac hydatid cysts with intracavitary expansion. Ann Thorac Surg 2001;71:1587-90.

5. Stojkovic M, Zwahlen M, Teggi A, et al. Treatment response of cystic echinococcosis to benzimidazoles: a systematic review. PLoS Negl Trop Dis 2009;3:e524.

This pdf has been created automatically from the final edited text and images.

Copyright 2012 BMJ Publishing Group. All rights reserved. For permission to reuse any of this content visit http://group.bmj.com/group/rights-licensing/permissions.

BMJ Case Report Fellows may re-use this article for personal use and teaching without any further permission.

Please cite this article as follows (you will need to access the article online to obtain the date of publication).

Shetty R, Vivek G, Nayak S, Dias L. A mysterious visitor to the heart. BMJ Case Reports 2012;10.1136/bcr-03-2012-6005, Published XXX

Become a Fellow of BMJ Case Reports today and you can:

- Submit as many cases as you like

- Enjoy fast sympathetic peer review and rapid publication of accepted articles

- Access all the published articles

- Re-use any of the published material for personal use and teaching without further permission

For information on Institutional Fellowships contact consortiasales@bmjgroup.com

Visit casereports.bmj.com for more articles like this and to become a Fellow 